Creative Commons User License: CC BY-NC-ND

Abstracted by: EBSCOhost, Electronic Journals Service (EJS)

Google Scholar, Journal Seek, Scientific Commons,

Food and Agricultural Organization (FAO), CABI and Scopus
Journal of Agricultural Extension

Vol. 23 (1) January, 2019

ISSN(e): 24086851; ISSN(Print); 1119944X

http://journal.aesonnigeria.org

http://www.ajol.info/index.php/iae

Email: editorinchief@aesonnigeria.org

\title{
Listenership of Latoju Oja Radio Extension Programme among Farmers in Oyo State, Nigeria
}

https://dx.doi.org/10.4314/jae.v23i1.6

\section{Fadairo AnjolaOluwa. 0}

Institute of Agricultural Research and Training, Obafemi Awolowo University, Moor Plantation, Ibadan. Email: anjolaorefadairo@gmail.com; Phone: +234-8036225908.

\section{Oyelami Benjamin. 0}

Department of Agricultural Extension, University of Ibadan.

Email:oyelamibo@gmail.com; Phone:+234-7062387036.

\begin{abstract}
This study assessed the listenership of latoju oja radio programme among farmers in Oyo state, Nigeria. Ninety farmers from three local government areas were randomly interviewed and data was analysed using descriptive and inferential statistics. Results revealed that the mean age of farmers was 47 years. Most of them (67.8\%) were Muslims, male (76.7\%), and married (94.4\%). Respondents had moderate level of education showing primary education (42.2\%) to be in the modal class. A high proportion (80.0\%) of the farmers were satisfied with the time of airing of latoju oja programme and considered it to be a useful source of information with a favourable disposition about the programme. Farmers disposition was highest in areas of enhancement of farmers bargaining power $(\bar{x}=4.53)$. The major constraint faced by respondents was how to sort out conflicting information provided by latoju oja radio programme $(\bar{x}=2.84))$. The findings indicated listenership to be low among a majority (58.9\%). A significant relationship existed between level of education $\left(x^{2}=3.99\right)$, benefits derived $(r=0.15)$ and listenership of latoju oja radio programme. Although latoju oja radio programme is well listened to, the information provided should be reconciled with the current market value so as to achieve the desired objective.
\end{abstract}

\section{Key words: Latoju oja radio programme, listenership, farmers}

\section{Introduction}

Agricultural extension service is established in order to impact knowledge, teach skills and change attitudes of people towards acceptance of innovation. Acceptance of innovations however has been premised on many factors relating more to farmers' personal views of such innovation (Ayoade and Akintonde, 2012). Therefore, there is a need to assist farmers to develop a frame of mind and attitude that will encourage adoption of new technologies. However, Fawole and Olajide (2012) found that the first step to consider in farmers use of information is their capacity to access the appropriate communication media. This thus shows that acceptance of new technologies can only be achieved with the use of an appropriate communication media type fully acceptable to farmers.

There are various communication media types utilized by agricultural extension workers, these include; (i) demonstrations such as: tours and field trips, pictures, exhibition display 
Creative Commons User License: CC BY-NC-ND

Abstracted by: EBSCOhost, Electronic Journals Service (EJS)

Google Scholar, Journal Seek, Scientific Commons,

Food and Agricultural Organization (FAO), CABI and Scopus
Journal of Agricultural Extension

Vol. 23 (1) January, 2019

ISSN(e): 24086851; ISSN(Print); 1119944X

http://journal.aesonnigeria.org

http://www.ajol.info/index.php/iae

Email: editorinchief@aesonnigeria.org

http://eoi.citefactor.org/10.11226/v23i1

among others, (ii) projected visuals such as films, flip charts, overhead projectors, chalkboard, flash cards amongst others and finally, (iii) mass media which include; radio, television and telephone calls. These media tools are used with the ultimate aim of improving farmer's knowledge and farming methods through adoption of new practices with a view to improving their wellbeing.

In addition to reaching out to farmers, appropriate communication media also ease message dissemination thereby relieving the extension worker of a huge assignment of covering a wide area. The use of media in extension work thus enables extension personnel operate more effectively. Mass media can serve as a potent tool to achieve this (Odiaka and Criscent, 2018; Age, Obinne and Demenongu, 2012). The mass media as a source of information utilizes three major channels of communication which are television, radio, and print. While these three channels have their various uses and importance, radio is considered the most effective and efficient in disseminating information to farmers over a wide area (Familusi and Owoeye, 2014). Also, Auma, Wangia, Ligare and K'obill (2017) posited that the fastest media channel that can disseminate accurate and relevant agricultural market information to mass of smallholder farmers is community radio.

Radio has been found to be one broadcast medium identified by almost all experts to be the most appropriate for rural liberation programmes. It cuts across distance as Uwandu, Thomas and Okoro (2018) found that mass media, especially radio play an important role in creating awareness about new agricultural technologies among farming communities across the world and thus has immediate effect. It has been considered the only medium of mass communication the rural population is familiar with (Yahaya, Adamson and Kareem, 2018). This is because a radio set is cheap to obtain and widely owned in rural areas since the advent of the battery operated transistorized sets. Furthermore, radio is favoured as a medium of communication in rural communities because it (i) transcends barriers of illiteracy and (ii) requires less intellectual exertion compared to print-media messages.

Olajide and Amusat (2012) report that radio farm broadcast in Nigeria can be traced to early 1960s when various regional governments in Nigeria, through the communication units of the ministries of agriculture, introduced the farm broadcast. Subsequently, all national agricultural intervention programme till date have made use of radio as potent tool of touching base with the targets and beneficiaries of development oriented programme in health, agriculture and environment. Uwandu et al (2018) observes that radio programmes are usually timely and capable of extending messages to target audience irrespective of location thereby bridging gaps that are palpable with difficult terrain, distance, topography, time and socio-political exigencies. The apparent innumerable advantages of radio over other mass media had endeared it to development and social workers, governments and non-government concerns who have continued to exploit such benefits. Hence, radio has been used in both developed and developing world in development intervention programme especially in agricultural information dissemination. Studies have equally reported radio as an effective channel of communication particularly in agricultural information for farmers' 
Creative Commons User License: CC BY-NC-ND

Abstracted by: EBSCOhost, Electronic Journals Service (EJS),

Google Scholar, Journal Seek, Scientific Commons,

Food and Agricultural Organization (FAO), CABI and Scopus

http://eoi.citefactor.org/10.11226/v23i1

benefits (Familusi and Owoeye, 2014). This has gone a long way to facilitate extension delivery as it perfectly complements the work of agricultural extension agents.

Attitudinal change and improvement in farmer's knowledge could thus be achieved with effective dissemination of information through radio. To achieve this objective however, Asogwa et al (2012) posit that the quality of information disseminated must rest on three pillars of accuracy, timeliness and relevance.

Effective market information dissemination to farmers is important as it facilitates their planning strategies like quantities to be purchased, quantity to be sold immediately and quantity to be stored (Zyang et al, 2016). However, poor access to relevant market information in developing countries has been identified in literature as a constraint to farmers' productivity and enlargement across the world. In Nigeria, Uwandu et al (2018) observe an inefficient market information system; meaning that there is a wide gap between farmers to processors and end-users, and no adequate and prompt information on market trends to control each of these farming activities appropriately.

The latoju oja radio extension programme, also known as the commodity trend is sponsored by the National Agricultural Extension and Research Liaison Services (NAERLS) of the Ahmadu Bello University (NAERLS/ABU). The institute is charged with the primary responsibility of research, development, collation, evaluation and dissemination of agricultural technologies to rural farm families and other interested end-users.

The institute grew out of the "Specialist Services" section of the former Northern Nigeria Ministry of Agriculture. With the transfer of Institute for Agricultural Research (IAR) Samaru in 1962 to the newly created Ahmadu Bello University, it became imperative to establish an organ to provide a formal link between IAR and the Ministry of Agriculture to ensure that research results get to farmers in useful and adoptable form. Thus the Research Liaison Section (RLS) was created in 1963 within the Ministry.

In 1975, the Ahmadu Bello University Council, in accordance with Statute 19, separated the ERLS from IAR and renamed it the Agricultural Extension and Research Liaison Services (AERLS). Thus, AERLS became an autonomous institute within the agricultural complex of the University under the guidance of the then Federal Ministry of Science and Technology (FMST), similar to the parent Institute, IAR.

Following the reorganization of the research institutes by the then Federal Ministry of Science and Technology, a number of changes in the mandates of several research institutes were announced in April, 1987. In recognition of its contribution to the successful extension support services in the Northern States of Nigeria, the AERLS thus earned a national mandate which transformed it to National Agricultural Extension and Research Liaison Services (NAERLS) which led to the establishment of five zonal offices one each in the five agro-ecological zone. 
Creative Commons User License: CC BY-NC-ND

Abstracted by: EBSCOhost, Electronic Journals Service (EJS)

Google Scholar, Journal Seek, Scientific Commons,

Food and Agricultural Organization (FAO), CABI and Scopus
Journal of Agricultural Extension

Vol. 23 (1) January, 2019

ISSN(e): 24086851; ISSN(Print); 1119944X

http://journal.aesonnigeria.org

http://www.ajol.info/index.php/iae

Email: editorinchief@aesonnigeria.org

http://eoi.citefactor.org/10.11226/v23i1

The NAERLS engaged in series of programme, part of which is the latoju oja radio programme falling under the Agricultural Media Programme. It is concerned with extension research in the areas of electronic and print media packages, channels of dissemination, audience surveys, feedback analysis, ICT use and extension support services covering radio \& TV programme, documentaries, jingles, extension publications in various languages, agricultural shows/fairs, etc.

The latoju oja radio extension programme is basically aimed at making relevant market information available to market participants in a form helpful to making decisions. The programme ensures the awareness of several prices of agricultural commodities across the five agro-ecological zones. Market information services have the function of collecting and processing market data systematically and continuously and making it available. It provides farmers adequate information on how to get and sell their agricultural commodities. This opportunity allows maximization of efforts and deployment of farm resources to meet clients' needs.

The radio broadcast, latoju oja was conceived to bridge the wide gap of timely provision of market information to the diverse target users and to achieve this, a mixture of rural and urban markets located in five locations in Nigeria namely, Zaria, Bida, Maiduguri, Umuahia, and Ibadan are being used to capture weekly prices of selected agricultural commodities using standard and familiar measures.

The information from these markets is tabulated capturing price variation across the country and aired on a weekly basis on the national radio stations. The programme is broadcasted for 15 minutes twice a week from 6:15 to 6:30 pm on Mondays in Yoruba language and Wednesdays in English language.

Therefore, against the background of poor agricultural market information access to rural farmers in Nigeria, this study seeks to ascertain the listenership status of latoju oja radio extension programme in Oyo State by providing answers to the following questions.

I. What are the socio-economic characteristics of the farmers?

II. What is the extent of listenership of Latoju Oja Radio programme among farmers?;

III. How satisfied are farmers with airing time of the programme?

IV. To what level have respondents made use of the information obtained from the programme?

$\mathrm{V}$. What are the perceived benefits derived from the radio programme? and

VI. What are the major constraints faced by respondents from benefiting maximally from the programme?

\section{Objectives of the study}

The general objective of the study was to determine the listenership of latoju oja radio extension programme among farmers in Oyo State, Nigeria while specific objectives include to:

- determine respondents' listenership of the programme;

- ascertain respondents' satisfaction with airing time of the programme; 
Creative Commons User License: CC BY-NC-ND

Abstracted by: EBSCOhost, Electronic Journals Service (EJS),

Google Scholar, Journal Seek, Scientific Commons,

Food and Agricultural Organization (FAO), CABI and Scopus
Journal of Agricultural Extension

Vol. 23 (1) January, 2019

ISSN(e): 24086851; ISSN(Print); 1119944X

http://journal.aesonnigeria.org

http://www.ajol.info/index.php/jae

Email: editorinchief@aesonnigeria.org

http://eoi.citefactor.org/10.11226/v23i1

- investigate level of use of agricultural information obtained from the programme;

- identify perceived benefit derived from the programme; and

- identify constraints faced by respondents from benefiting maximally from the programme.

\section{Methodology}

The study was carried out in Oyo State, Nigeria on latitude $8.1196^{\circ} \mathrm{N}$ and longitude $3.4196^{\circ} \mathrm{E}$. There are 33 local government areas (LGAs) in Oyo state grouped into five (5) geographical zones including Ibadan, Oke -ogun, Ogbomoso, Oyo and Ibarapa zones. Ibadan and Oyo zones were purposively selected considering proximity to the location of the radio station where latoju -oja programme is aired. Ibadan zone has 11 LGAs while Oyo zone has 4 LGAs. Randomly, 20\% of LGAs from each of the identified zones were selected to give 2 and 1 LGAs from lbadan and Oyo Zones, respectively. They included Akinyele and Lagelu LGAs from Ibadan zones and Afijio LGA and were selected. The inhabitants engage primarily in farming and trading activities while agro-allied processing small scale industries and services establishment like catering and restaurants are available in many settlements.

Thirty three $(33 \%)$ of the prominent towns in each of the selected LGAs were randomly chosen. This translated to three out of the 9 town communities in Akinyele LGA, three out of eight 3 out of 8 communities in Lagelu and 2 out of the 6 communities in Afijio LGA, making a total of 8 communities in all. These communities are; Alabata, ljaye and Akinyele in Akinyele LGA, Lalupon, Ejioku and Oyedeji in Lagelu LGA as well as Jobele and Imini communities in Afijio LGA. Using systematic random sampling, $10 \%$ of households were selected in each of the communities. A total of 33,29 and 28 respondents, respectively from each LGA were interviewed using structured open and close ended questionnaire to give a total of 90 respondents.

Independent variables considered in the study included personal characteristics of respondents, satisfaction with airing time and extent of information use while the dependent variable was farmers' listenership of latoju-oja radio programme. Listenership of Latoju-oja radio programme was operationalised using 5 domains with different response categories. These domains included listenership of Latoju-oja radio programme measured on a yes/no scale, frequency of listening on three response categories of seldom, often and very often, mode of listening which was either alone or under a group platform; this was further structured on response options of, with relations or with neighbours, and respondents' reasons for listening to Latoju-oja radio programme which was either for relaxation, to obtain information or for entertainment.

Responses obtained from each domain were pooled together, standardized and computed to obtain a mean score of $8.5 \pm 1.4$. Using the mean score as a bench mark, respondents who scored the mean and above were categorised as high listeners while those whose scores were below the mean were categorised as low listeners. Data were summarized with the use of tools such as frequencies, percentages and means while inferential statistics such as chi-square and Pearson Product Moment Correlation (PPMC) were used to

describe the relationships that existed between the independent variables and the dependent variables. 
Creative Commons User License: CC BY-NC-ND

Abstracted by: EBSCOhost, Electronic Journals Service (EJS)

Google Scholar, Journal Seek, Scientific Commons,

Food and Agricultural Organization (FAO), CABI and Scopus

http://eoi.citefactor.org/10.11226/v23i1
Journal of Agricultural Extension

Vol. 23 (1) January, 2019

ISSN(e): 24086851; ISSN(Print); 1119944X

http://journal.aesonnigeria.org

http://www.ajol.info/index.php/iae

Email: editorinchief@aesonnigeria.org

\section{Results and Discussion}

\section{Personal Characteristics of Respondents}

Table 1 shows the distribution of farmers with respect to their personal characteristics. The table shows that the mean age of the respondent was 47 years. The findings show that agricultural activities are still in the hands of ageing farmers. This may be due to the problem of rural-urban migration of youth below 30 years of age. Perhaps, the idea of having ageing farmers in farm settlement could be deduced as reasons for the trend observed in this study as it supports familiar drift of small holder, little education and quite older population in previous studies (Akinnagbe, Adeniran and Adeniran, 2018; Ballo, Olutegbe and Adekoya, 2018). Also, the table reveals that $76.7 \%$ were male. This implies that the male farmers listen more to the latoju oja radio programme in the study area compared to their female counterpart. This may be as a result of females' engagement in household activities which hinders them from listening. Majorities (94.4\%) of the respondents were married and of Islamic religion (67.8\%), which suggest the predominance of Muslims in the study area compared to the other religion. Likewise, the table reveals that $74.4 \%$ of the respondents had at least primary school education. This implies that the majority had a moderate level of literacy in the study area. However, this finding is in tandem with findings of Umeokeke et al (2017) which reported high level of literacy among farmers in Ibadan city and Njoku (2016) reported a mean level of years spent in school among agricultural radio programme listeners in Imo state as 8.5 years.

Table 1: Personal characteristics of the respondents

\begin{tabular}{lll}
\hline Variables & Percentage & Mean \\
\hline Age & & 46.9 \\
$21-30$ & 5.6 & \\
$31-40$ & 28.9 & \\
$41-50$ & 24.4 & \\
$51-60$ & 33.3 & \\
$>60$ & & \\
Sex & 76.7 & \\
Male & 23.3 & \\
Female & 4.4 & \\
Marital status & 94.4 & \\
Single & 1.1 & \\
Married & 32.2 & \\
Divorced & 67.8 & \\
Religion & & \\
Christianity & & \\
Islam & 25.6 & \\
Education & 42.2 & \\
Non formal & 22.2 & \\
Primary & 10.0 \\
Secondary & & \\
Tertiary & & \\
Farm size & 57.8 & \\
5-7 & 27.9 & \\
$>7$ & 14.5 &
\end{tabular}

Source: Field work, 2017 
Creative Commons User License: CC BY-NC-ND

Abstracted by: EBSCOhost, Electronic Journals Service (EJS)

Google Scholar, Journal Seek, Scientific Commons,

Food and Agricultural Organization (FAO), CABI and Scopus
Journal of Agricultural Extension

Vol. 23 (1) January, 2019

ISSN(e): 24086851; ISSN(Print); 1119944X

http://journal.aesonnigeria.org

http://www.ajol.info/index.php/jae

Email: editorinchief@aesonnigeria.org

http://eoi.citefactor.org/10.11226/v23i1

\section{Listenership of Latoju Oja Radio Programme among Farmers}

Table 2 reveals that all the respondents listened to latoju oja programme. About $75.5 \%$ listened to the programme either often or very often and alone (64.4\%) most of the time they did so. This suggests that latoju-oja is a popular radio programme in the study area and most farmers avoid possible distraction when listening. Studies have found that rural farmers prefer listening to community radio and most times they listen to it daily and that rural development programme in Nigeria have wide listenership base (Auma et. al., 2017; Akinnagbe et al, 2018). The majority (63.3\%) listened to the programme for the purpose of getting information. This thus implies that latoju-oja programme is highly informative on market prices to the farmers.

Furthermore, shows that listenership of the programme was low among the majority (58.9\%) of the respondents. This finding is opposed to previous findings by Familusi and Owoeye (2014) which observed a high listenership index for radio programme among farmers in Nigeria, and Fadairo (2012) which also observed a high listenership of radio programme among pastoralists and migrants' fisher folks in Nigeria. The low listenership of the latoju oja suggests poor or inadequate impact of the programme among the target audience in the study area. This is because listenership entails more than mere listening to the programme but includes frequency of listening and purpose of listening. This results shows that only $23.3 \%$ listened very often and a little above average (63.3\%) listened for educational purpose. This could have influenced the categorization respondents' listenership.

\section{Table 2: Listenership of latoju oja radio programme among farmers}

\begin{tabular}{lll}
\hline Statements & Response category & $\%$ \\
\hline Do you listen to latoju oja radio programme & No & - \\
& Yes & 100.0 \\
Frequency of listening & Seldom & 24.4 \\
& Often & 52.2 \\
& Very often & 23.3 \\
Mode of listening to the programme & Alone most of the time & 64.4 \\
& With others most of the & 35.5 \\
& time & \\
If with others, who are they? & Relations & 31.1 \\
What is your reason for listening to the & Neighbours & 4.4 \\
programme & Relaxation & 25.6 \\
& Education/information & 63.3 \\
Listenership & Entertainment & 11.1 \\
& Low (7-8) & 58.9 \\
& High (9-19) & 41.1 \\
\hline
\end{tabular}

$\overline{\boldsymbol{x}}=8.5 \mathrm{SD}=1.40$

\section{Satisfaction with Airing Time}

Figure 1 indicates the distribution of respondents based on satisfaction with time of airing (6.15 pm $-6.30 \mathrm{pm}$ on Mondays and Wednesdays) the latoju oja radio programme. Result shows that $80.0 \%$ of the respondents were satisfied with the time of airing of the programme (Figure 1). This, in essence guarantees that the respondent would listen to the progamme and give maximum attention to the programme to be able to utilise necessary information provided by the latoju oja radio programme. The trend observed in the result can be attributed to broadcast of the programme in two different languages (English and Yoruba) 
and suitability of broadcast hour being in the evening. Although, this result contradicts the findings of Ango et al (2013) that the majority of farmers in Zaria listened to radio agricultural programmes in the morning time before going to farm, it also suggests that the convenient time of listening to radio programs by farmers in these two locations differs. Familusi and Owoeye (2014) observed that most farmers observe the period of listening to radio as leisure time in most farm settlements. In line with this, the finding thus suggests that farmers in the study area always have their relaxation in the evening around the time of broadcast of latoju oja. The listeners would also have the opportunity to discuss relevant issues in the broadcast with their friends to aid mutual understanding.

\section{Figure 1: Distribution of respondents by satisfaction on time of airing of latoju oja programme}

\section{Level of Use of Information Derived from the Programme}

Figure 2 indicates the level of use of information obtained from latoju oja radio programme. All respondents considered the programme a useful source of market price information in agricultural enterprise. Half of the respondents $(50.0 \%)$ described the information to be very useful and the remaining half indicated it to be less useful. This implies that the latoju oja radio programme is a useful source of market information. It therefore denotes that the information helps farmers to understand what obtains in the market and therefore offers direction and guidance to farmers in managing market risks and aid proper decision making. 
Creative Commons User License: CC BY-NC-ND

Journal of Agricultural Extension

Abstracted by: EBSCOhost, Electronic Journals Service (EJS), Vol. 23 (1) January, 2019

Google Scholar, Journal Seek, Scientific Commons,

Food and Agricultural Organization (FAO), CABI and Scopus

http://eoi.citefactor.org/10.11226/v23i1
ISSN(e): 24086851; ISSN(Print); 1119944X

http://journal.aesonnigeria.org

http://www.ajol.info/index.php/jae

Email: editorinchief@aesonnigeria.org

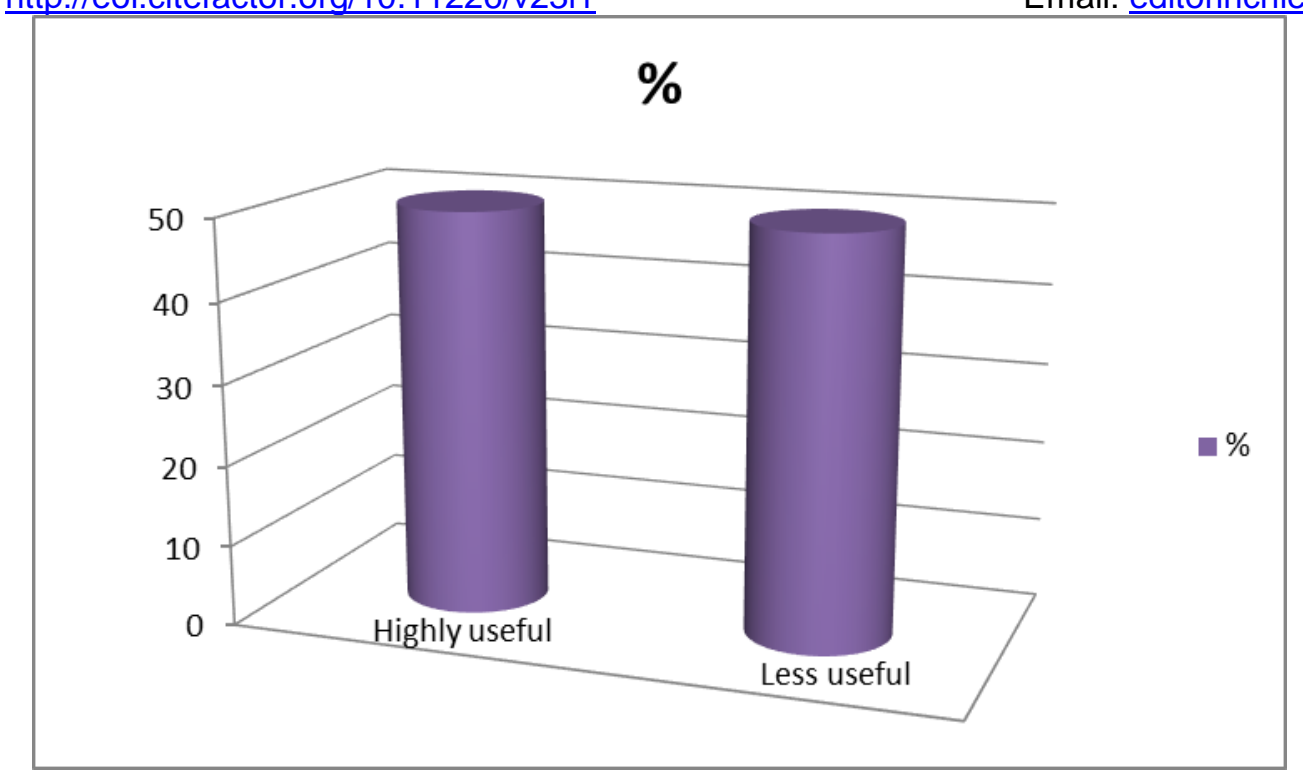

Figure 2: Level of use of information obtained from the latoju oja programme.

\section{Perceived Benefits Derived from Latoju oja Radio Rrogramme}

Table 3 indicates the respondents perceived benefits derived from the programme. It reveals that most of the respondents were not-favourably disposed to the perception statements on perceived benefits derived from the programme. For instance, although the respondents agreed overwhelmingly that information provided by the programme had been useful in price bargaining of their agricultural produce $(\overline{\boldsymbol{x}}=4.53)$. The next two ranked statements; the programme is more useful to few farmers $(\overline{\boldsymbol{x}}=$ 4.38) and not really worth the time invested in it $((\bar{x}=4.33)$ were negatively worded statements. This implies that the information disseminated in the programmes is only beneficial to some aspect of agricultural productions which is not a major concern to most of the farmers. Furthermore, respondents did not indicate agreement for statements that the programme has helped to boost market of agricultural produce $(\overline{\boldsymbol{x}}=4.07)$. What this implies is that the latoju oja is not of maximum benefit to most of the farmers as it is expected to be. 
Abstracted by: EBSCOhost, Electronic Journals Service (EJS), Vol. 23 (1) January, 2019

Google Scholar, Journal Seek, Scientific Commons,

ISSN(e): 24086851; ISSN(Print); 1119944X

Food and Agricultural Organization (FAO), CABI and Scopus

http://journal.aesonnigeria.org

http://www.ajol.info/index.php/iae

http://eoi.citefactor.org/10.11226/v23i1

Email: editorinchief@aesonnigeria.org

Table 3: Perceived benefits derived from the programme

\begin{tabular}{|c|c|c|}
\hline Statements & Mean & Rank \\
\hline $\begin{array}{l}\text { Information provided by latoju oja have been useful in my price } \\
\text { bargaining in marketing of agricultural produce }\end{array}$ & 4.53 & $1^{\text {st }}$ \\
\hline The programme addresses my information needs & 4.11 & $8^{\text {th }}$ \\
\hline $\begin{array}{l}\text { The category of commodities covered by the programme is only beneficial } \\
\text { to some few farmers }\end{array}$ & 4.38 & $2^{\text {nd }}$ \\
\hline $\begin{array}{l}\text { Information derived from the programme has contributed to increase of } \\
\text { farm income }\end{array}$ & 4.13 & $5^{\text {th }}$ \\
\hline $\begin{array}{l}\text { Information derived from the programme has contributed to the } \\
\text { development of new market for my produce }\end{array}$ & 4.12 & $6^{\text {th }}$ \\
\hline Over the years the programme has help to boost sales of my produce & 4.07 & $9^{\text {th }}$ \\
\hline $\begin{array}{l}\text { Information derived from the programme has aided proper decision and } \\
\text { increase farm gate prices }\end{array}$ & 4.11 & $8^{\text {th }}$ \\
\hline $\begin{array}{l}\text { The benefits I derive from the programme is not worth the time invested in } \\
\text { listening to it }\end{array}$ & 4.33 & $3^{\text {rd }}$ \\
\hline $\begin{array}{l}\text { Information obtained from the programme prevents exploitation of farmers } \\
\text { by middlemen }\end{array}$ & 4.12 & $6^{\text {th }}$ \\
\hline
\end{tabular}

\section{Constraints Faced by Respondents}

Table 4 shows that inaccuracy of information obtained from radio programme when compared with the actual market prices was the major constraints faced by respondents. This was followed by poor feedback opportunity and lack of regular power supply which ranked as 2 and 3 respectively. On the other hand, constraints such as unstable signal and poor public relation of the presenter ranked low with rank of 7 in each case.

\begin{tabular}{|c|c|c|}
\hline Constraints & Mean & Rank \\
\hline Frequency network or signal is usually unstable & 1.0 & $7^{\text {th }}$ \\
\hline Lack of constant/regular power supply to listen to the programme & 1.93 & $3^{\text {rd }}$ \\
\hline Poor public relation of the radio presenter & 1.0 & $7^{\text {th }}$ \\
\hline Time scheduled for the programme is inadequate & 1.50 & $4^{\text {th }}$ \\
\hline Information is not broadcast on radio in preferred dialect & 1.0 & $7^{\text {th }}$ \\
\hline Poor feedback opportunity & 2.40 & $2^{\text {nd }}$ \\
\hline Boredom as a result of frequently repeated editions & 1.11 & $6^{\text {th }}$ \\
\hline $\begin{array}{l}\text { Information from latoju oja sometimes contradicts what obtains in } \\
\text { the market }\end{array}$ & 2.84 & $1^{\text {st }}$ \\
\hline The broadcast hour for latoju oja is inappropriate & 1.40 & $5^{\text {th }}$ \\
\hline The broadcast hour for latoju oja is inappropriate & 1.0 & $7^{\text {th }}$ \\
\hline
\end{tabular}

(Figures in parentheses are percentages) 
Creative Commons User License: CC BY-NC-ND

Abstracted by: EBSCOhost, Electronic Journals Service (EJS),

Google Scholar, Journal Seek, Scientific Commons,

Food and Agricultural Organization (FAO), CABI and Scopus
Journal of Agricultural Extension

Vol. 23 (1) January, 2019

ISSN(e): 24086851; ISSN(Print); 1119944X

http://journal.aesonnigeria.org

http://www.ajol.info/index.php/jae

Email: editorinchief@aesonnigeria.org

http://eoi.citefactor.org/10.11226/v23i1

\section{Relationship between the Personal Characteristics of Respondents and Listenership of latoju oja Radio Programme}

Table 5 shows no significant relationship between the respondents sex $\left(x^{2}=2.91\right)$, marital status $\left(x^{2}=3.70\right)$, religion $\left(x^{2}=0.01\right)$ and listenership of latoju oja radio programme. $\mathrm{A}$ significant relationship was however observed between their level of education $\left(x^{2}=3.99\right)$ and listenership of latoju oja radio programme. This implies that respondent's sex, marital status and religion are not associated with their listenership. The positive association between level of education and listenership of respondents might be well explained that education influences individual knowledge of the programme and ultimately affects his/her listenership, attitude and behaviour. This is because more literate individuals are in better position to access information and utilize them. Also, table 5 shows no significant correlation between respondents age $(r=0.33)$, farm size $(r=0.01)$ and listenership of latoju Oja radio programme. This result also suggests that farmers' age and farm size have no significant link to their listenership of latoju Oja radio programme. Previous study by Anglo et al (2013) likewise found no significant relationship between farmers' age and their effectiveness of listening and use of radio agricultural programme. The foregoing thus implies that farmer's level of education influences their listening habit to radio agricultural programmes than every other listed characteristic.

Table 5: Relationship between personal characteristics and listenership of latoju oja programme

\begin{tabular}{lll}
\hline Variables & df & $\boldsymbol{x}^{2}-$ value \\
\hline Sex & 1 & 2.908 \\
Marital status & 2 & 3.696 \\
Religion & 1 & 0.001 \\
Level of Education & 3 & $3.991^{*}$ \\
\hline
\end{tabular}

* Significant $p \leq 0.05$

\section{Relationship between Respondents' Perceived Benefit and Listenership of Latoju Oja Radio Programme.}

Table 6 shows a significant correlation between respondents' perceived benefits $(r=0.15)$ and listenership of latoju oja radio programme. This implies that respondents' perceived benefit is associated with listenership of latoju oja radio programme. This means that benefit derived from the programme affects listenership habits of the respondents. However, the findings in this study (Table 3 ) show that the majority $(58.9 \%)$ perceived the benefit as low, which thus suggests that despite the perceived low benefit derived, the radio programme is still worth the time and effort given to listening to it. Aside from advantages that farmers perceive to benefit from radio agricultural programmes, Olajide and Amusat (2012) posits that farmers derive benefits in several other ways helpful in marketing of their agricultural produce. The summation of perceived and these other benefits could have could have therefore contributed significantly to the farmers listenership of latoju Oja radio programme. 
Creative Commons User License: CC BY-NC-ND

Abstracted by: EBSCOhost, Electronic Journals Service (EJS)

Google Scholar, Journal Seek, Scientific Commons,

Food and Agricultural Organization (FAO), CABI and Scopus

http://eoi.citefactor.org/10.11226/v23i1
Journal of Agricultural Extension

Vol. 23 (1) January, 2019

ISSN(e): 24086851; ISSN(Print); 1119944X

http://journal.aesonnigeria.org

http://www.ajol.info/index.php/iae

Email: editorinchief@aesonnigeria.org

\section{Table 6: Correlation between respondents perceived benefits derived and listenership of latoju oja}

\begin{tabular}{ll}
\hline Variables & $\mathrm{r}$ - value \\
\hline $\begin{array}{l}\text { Perceived benefits and } \\
\text { Listenership }\end{array}$ & $0.15^{\star}$ \\
\hline${ }^{*} \mathrm{P} \leq 0.05$ &
\end{tabular}

\section{Conclusion and Recommendations}

This study concluded that listenership of latoju oja radio programme was low among farmers in Oyo state. This is because information from latoju oja sometimes contradicts what obtains in the market, and poor feedback opportunity available during airing of the programme.

Respondents are significantly influenced by various factors which may in one way or the other limits the listenership of the programme by respondents to bring about improvements in agricultural practice through prompt and adequate market information.

A review of time duration for the programme from the current two sessions per week and fifteen minutes' duration to more sessions during the week and for longer period.

Feed- back mechanism should be made available in order to allow the listeners call in and make complaints of confusing information and also contribute.

Advocacy for multi-agency sponsor of the programme to buy more airtime for the broadcast of the latoju oja radio programme.

Emphasis should be given to disseminate useful information about market risks through the radio programme.

\section{References}

Age A I, Obinne C. P. O and Demenongu T. S (2012). Communication for sustainable rural and agricultural development in Benue State, Nigeria. Sustainable Agriculture Research 1 (1): $118-129$.

Akinnagbe O. M, Adeniran T. P and Adeniran A, A (2018). Intra-Household Roles in Cocoa Production in Ondo State, Nigeria. Journal of Agricultural Extension 22 (3): 77 - 86.

Anglo A K, Illo A. I, Abdullahi A. N, Maikasuwa M. A and Amina A (2013). Role of farm-radio agricultural programmes in disseminating agricultural technology to rural farmers for agricultural development in Zaria, Kaduna State, Nigeria. Asian Journal of Agricultural Extension, Economics and sociology 2 (1): $54-68$.

Asogwa, B. C., Ezihe, J. A. C., and Ogebe F. O. (2012). Agricultural marketing information usage among soybean farmers in Nigeria. International Journal of Innovation and Applied Studies 1 (2): 160-170.

Auma P, Wangia S.M, Magomere T., Ligare E.C and K'obill J. (2017). Effectiveness of Community Radio in Market Information among smallholder Maize Farmers: Experience from Suba Sub-community Kenya. International Journal of Innovative Research and Development 6 (3): 54 - 63. 
Creative Commons User License: CC BY-NC-ND

Abstracted by: EBSCOhost, Electronic Journals Service (EJS),

Google Scholar, Journal Seek, Scientific Commons,

Food and Agricultural Organization (FAO), CABI and Scopus
Journal of Agricultural Extension

Vol. 23 (1) January, 2019

ISSN(e): 24086851; ISSN(Print); 1119944X

http://journal.aesonnigeria.org

http://www.ajol.info/index.php/jae

Email: editorinchief@aesonnigeria.org

http://eoi.citefactor.org/10.11226/v23i1

Ayoade A.R and Akintode J.O (2012). Constraints to Adoption of Agricultural Innovations among Women Farmers in Isokan Local Government Area, Osun State. International Journal of Humanities and Social Science 2 (8): 57 - 61.

Ballo M., Olutegbe N.S and Adekoya A. E (2018). Welfare Status of Rice Farming Household in Office Du Niger, Segou Region of Mali. Journal of Agricultural Extension 22 (3): $64-76$.

Fadairo A. O (2012). Viewership and Listenership of Health - Related Entertainment Education Programmes among Women in Lagos State, Nigeria. Journal of Agriculture, Forestry and Social Sciences 10 (1): $13-21$.

Familusi E. B. and Owoeye P. O. (2014). An assessment of the use of radio and other means of Information dissemination among the residents of Ado- Ekiti, Nigeria. $\begin{array}{llll}\text { Library philosophy and Practice (e-journal). } 1088 . & \end{array}$ http://digitalcommons.unl.edu/libphilprac/1088

Fawole O.P and Olajide R. (2012). Awareness and Use of Information Communication Technologies by Farmers in Oyo State, Nigeria. Journal of Agriculture and Food Information 13 (4): 326 - 337.

Njoku, J. I. K. (2016). Effectiveness of radio-agricultural farmer programme in technology transfer among rural farmers in Imo State, Nigeria. Net journal of Agricultural Science 4 (3): $22-28$.

Odiaka, E. C.; Criscent, I.E. (2018). Mass media coverage of agricultural information: the Benue State example. Journal of Agricultural Extension 11(1): $45-54$. Available at: <http://journal.aesonnigeria.org/index.php/jae/article/view/1639>. Date accessed: 21 Nov. 2018.

Olajide B.R. and Amusat A. S. (2012). Perceived efficacy of radio agricultural commodities trend programme among farmers in Oyo State, Nigeria. Journal of Media and Communication studies 4(3): $46-51$.

Umeokeke N. I, Okoruwa V. O. and Adeyemo T. A (2017). Impact of Electronic Wallet system on farmer's welfare in Oyo State, Nigeria. International Journal of Social Economics 44(4): $474-490$.

Uwandu C.N, Thomas K.A and Okoro C.M (2018). Utilization of Agricultural Information Sources and Adoption of Animal and Crop Technology among farming Households in Imo State, Nigeria. Journal of Agricultural Extension 22 (1): 143 - 155.

Yahaya M.K, Adamson F.A and Kareem I T. (2018). Coverage of Agricultural Programmes in Broadcast Stations in Oyo State. Journal of Agricultural Extension 22 (3): 22 - 30.

Zyang Y., Wang L and Duan Y. (2016). Agricultural information dissemination using ICTs: A review and analysis of information dissemination models in China. Journal of Information processing in Agriculture 3(1): 17 - 29. 